\title{
Samhandlingsreformen og akuttmedisinen
}

\author{
Samhandlingsreformen stiller nye krav til det akuttmedisinske samarbeidet. Dette er en gyllen anledning \\ til å etablere akuttmedisinen som eget fagområde.
}

ab

Engelsk oversettelse av hele artikkelen på www.tidsskriftet.no

Fremtidige samfunnsøkonomiske og demografiske utfordringer tvinger frem en mer effektiv drift av helse- og omsorgssektoren i Norge. Samhandlingsreformen (1) legger kursen, den nye nasjonale helse- og omsorgsplanen (2) kommer med retningslinjene for hvordan regjeringen ønsker å sikre effektiv og adekvat pasientbehandling. Om dette vil ha konsekvenser for akuttmedisinen, er avhengig av hvordan man definerer begrepet.

Akuttmedisin defineres $\mathrm{i}$ «Forskrift om akuttmedisin utenfor sykehus» som kvalifisert medisinsk diagnostikk, rådgivning, behandling og/eller overvåking ved akutt oppstått eller forverring av sykdom eller skade, herunder akutte psykiske lidelser, der rask medisinsk hjelp kan være avgjørende for liv og helse (3). I Norge blir akuttmedisin i første rekke oppfattet som «blålysmedisin» (4), men det er viktig å poengtere at dette er et bredt og omfattende fagfelt som omfatter tilstander og sykdommer med ulik alvorlighetsgrad. Akuttmedisin er all medisin som praktiseres i sykehusenes akuttmottak og/eller prehospitalt.

Tidligere helseminister Bjarne Håkon Hanssen uttalte ved fremleggelsen av samhandlingsreformen at «det er store gevinster å hente ved å oppdage sykdom tidlig...», men samtidig at de færreste kommuner hadde systemer som kunne følge opp pasienter med gryende symptomer på alvorlig kronisk eller langvarig sykdom (1). Det er naturlig at oppfølging og bedre ivaretakelse ved kroniske sykdomsforløp vil kunne redusere de akutte forverringene av noen sykdommer. Samhandlingsreformen bygger på en forutsetning om at det er mange unødvendige sykehusinnleggelser. Hvor stor innvirkning bedre oppfølging i primærhelsetjenesten vil få på det akutte behandlingsapparatet i sykehusene, er foreløpig usikkert.

I Norge utgjør akuttinnleggelsene omtrent $45 \%$ av alle innleggelser og domineres av indremedisinske lidelser (2). De aller fleste innlegges via akuttmottaket. Sett under ett har det vært en økning i antall akuttinnleggelser her $i$ landet på rundt $3-5 \%$ i de senere år (3). Data viser at det først og fremst er blant de eldre (over 65 år) $i$ befolkningen at innleggelse for akutte tilstander øker (3). Det er spådd en økning $i$ antall eldre i de kommende årene, og store sykdomsgrupper som dominerer i høy alder vil øke i utbredelse med $40-60 \%$ frem mot 2030 (4). Det er spådd at pleiebehovet vil øke med minst $60 \%$. Den samme tendensen ses i en rekke land (5). Mye tyder på at det er en reell økning i antall personer med behov for akuttjenester, ikke økt antall innleggelser/besøk per person. Man ser en $ø \mathrm{kning}$ som er sterkere for medisinske tilstander enn for de kirurgiske og som primært er knyttet til eldre aldersgrupper.

En betydelig del av dem som ankommer akuttmottaket er henvist fra legevakten, bare $12 \%$ av innleggelsene blir gjort av pasientens fastlege (6). En faktor som kan påvirke beslutningen om innleggelse er hvor godt innleggende lege kjenner
Helsedirektoratet har fått i oppdrag å etablere et forsøk med videreutdanning (kompetanseområde) i akuttmedisin for leger (10). Dette vil være et steg i riktig retning for å kunne definere og sikre det fremtidige behovet for den akuttmedisinske breddekompetanse som etterspørres. Nasjonalt kompetansesenter for legevaktmedisin skriver i «Forslag til Nasjonal handlingsplan for legevakt» at legevakten i fremtiden vil bli «mer innrettet mot beredskap, akuttmedisin og det som haster» (11). Akuttmottakene vil således være en egnet arena for kompetansebygging innen akuttmedisin.

\section{«Ved å etablere akuttmedisin som et fag- område vil man tydeliggjøre hvilken kompetanse som kreves og dermed lettere kunne definere ansvar og oppgavefordeling innen den akutt- medisinske kjeden»}

pasienten. De som ankommer akuttmottaket via legevakten behandles ikke i større grad poliklinisk der (7). Dette kan selvfølgelig tyde på at det ikke er lagt til rette for et utredende og behandlende akuttmottak, men det kan også tolkes slik at disse pasientene har et tilsvarende behov for spesialisthelsetjenesten som dem som ankommer akuttmottaket direkte. Ved analyse av pasientdata samt bedre samhandling mellom primærhelsetjenesten og akuttmottaket vil man i større grad prehospitalt kunne selektere dem som bør sendes direkte til spesialisthelsetjenesten.

I samhandlingsreformen er hovedintensjonen «rett behandling på rett sted til rett tid». Dette forutsetter at det helsepersonellet som skal ivareta den som blir akutt syk, må inneha den nødvendige akuttmedisinske breddekompetanse, uavhengig av organisering. Legevaktlegen har en viktig rolle som «portvakt» mellom primærhelsetjenesten og spesialisthelsetjenesten (8). I Helsetilsynets gjennomgang av norske somatiske akuttmottak i 2007 ble kompetansen i akuttmottakene beskrevet som et «risikoområde» (9). I dette lå risikoen for at den nødvendige kompetanse ikke var til stede ved mottak av akutte syke, fordi man ofte satte de minst erfarne legene til dette arbeidet.
Dette vil kunne gi bedre innsikt i og dypere forståelse mellom de samarbeidende enheter i primær- og spesialisthelsetjenesten. Det er ikke uten grunn at man i Danmark har valgt å definere ett felles kompetanseområde i akuttmedisin for allmenn- og sykehusleger.

Samhandlingsreformen gir utfordringer og konsekvenser det er vanskelig fullt ut å forutse, selv om noen rammeforutsetninger er skissert. Utfordringene ligger i å definere de nødvendige grenseflatene mellom de ulike enhetene $i$ et behandlingsforløp.

Hensikten med samhandlingsreformen er ikke å pålegge primærhelsetjenesten å drive spesialistbehandling, men å tydeliggjøre og øke samarbeidet. Da er det av stor betydning at man sørger for nødvendig og tydelig ansvarsfordeling mellom tjenestene samt adekvat kompetanse i alle ledd til å ivareta de oppgavene man får tildelt. Ved å etablere akuttmedisin som et fagområde vil man tydeliggjøre hvilken kompetanse som kreves og dermed lettere kunne definere ansvar og oppgavefordeling innen den akuttmedisinske kjeden.

\section{Oddvar Uleberg}

oddvar.uleberg@stolav.no

Lars Petter Bjørnsen

Akuttmedisinsk fagavdeling

St. Olavs hospital 
Oddvar Uleberg (f. 1974) er konstituert avdelingssjef, overlege og spesialist i anestesiologi. Ingen oppgitte interessekonflikter.

Lars Petter Bjørnsen (f. 1975) er tidligere kommunelege. Han er overlege og spesialist innen akuttmedisin fra USA og leder av Norsk Selskap for Akuttmedisin (NORSEM).

Ingen oppgitte interessekonflikter.

\footnotetext{
Litteratur

1. Stoltenberg J, Hanssen BH. Rett behandling til rett tid. Arbeiderpartiet.no. 20.6.2009

http://arbeiderpartiet.no/Aktuelt/Kommentarer/ Rett-behandling-til-rett-tid. (28.11.2011).
}

2. Lokalsykehusenes akuttfunksjoner i en samlet behandlingskjede. Sluttrapport fra arbeidsgruppe 19.3.2007. Oslo: Helse- og omsorgsdepartementet, 2007.

3. SAMDATA Nøkkeltall for spesialisthelsetjenesten 1.9.2008. Trondheim: SINTEF, 2008

4. Scenario 2030 - sykdomsutviklingen for eldre fram til 2030. IK-2696. Nasjonalt Geriatriprogram, 6-99. Oslo: Statens helsetilsyn, 1999

5. Acute medical admissions - a critical appraisal of the literature. NZHTA Report 6/1998. Chistchurch, N.Z.: New Zealand Health Techonolgy Assessment (NZHTA) - the Clearing House for Health Outcomes and Health Technology Assessment, 1998.

6. Eikeland G, Garåsen H, Jacobsen G. Finnes det alternativer til øyeblikkelig hjelp-innleggelser? Tidsskr Nor Lægeforen 2005; 125: 2355-7.

7. Diagnostiske og logistiske variabler innhentet fra Akuttdatabasen (Versjon 1.5.5. Copyright (c) Helse Vest IKT) ved Akuttmottaket på St Olavs Hospital (interne data). Trondheim: St. Olavs hospital, 2011 8. Zakariassen E. Akuttmedisinske henvendelser til AMK-sentraler i Norge - epidemiologi, hvem varsles og hvem rykker ut. Scandinavian Update Magazine 2010; 3: 54- 7 .

9. Helsetilsynet. «MENS VI VENTER ...»-forsvarlig pasientbehandling i akuttmottakene? Oppsummering av landsomfattende tilsyn i 2007 med forsvarlighet og kvalitet i akuttmottak i somatisk spesialisthelsetjeneste. Rapport. Oslo: Helsetilsynet, 2008. www.helsetilsynet.no/upload/Publikasjoner/ rapporter2008/helsetilsynetrapport2_2008.pdf (28.11.2011).

10. St.meld. nr. 16 (2010-2011). Nasjonal helse- og omsorgsplan (2011-2015).

11. ... er hjelpa nærmast! Forslag til Nasjonal handlingsplan for legevakt. Rapport nr. 1. Bergen: UNIFOB HELSE, Nasjonalt kompetansesenter for legevaktmedisin, 2009.

Mottatt 23.11. 2011 og godkjent 28.11. 2011. Medisinsk redaktør Anne Kveim Lie.

\title{
Samhandlingsreforma - på feil spor
}

\author{
I samhandlingsreforma er det gode intensjonar om meir satsing på primærhelsetenesta og godt samarbeid \\ med spesialisthelsetenesta. Desse intensjonane ser ut til å drukne i pengeflytting og forhasta avtalearbeid.
}

Sjølvsagt skal vi samhandle! I ei tid der kunnskapsmengda veks ekspotensielt, er spesialisering uunngåeleg. Dette gjer oss meir avhengige av kvarandre for å belyse fleire bitar av puslespelet. Det gjer allmennlegen enda viktigare som integrator og samlar av trådar. Samhandling er ein nøkkel for å få dette til å fungere. Hovedelementa må vere god kommunikasjon, utveksling av informasjon og kunnskap og ei god oppgavefordeling der pasientane blir teke vare på i heimkommunen, der dette er rett og forsvarleg, og vist til spesialisthelsetenesta, der dette er nødvendig.

Denne oppgavefordelinga må skje på eit fagleg grunnlag, slik at pasientane er sikra forsvarleg utgreiing og behandling. Vi treng først og fremst godt fagleg utviklingsarbeid i samarbeid mellom primærlegar og sjukehuslegar. Dette er ikkje nytt, eg minner om prosedyrepermarbeidet lokallaga i Legeforeningen dreiv i 1990-åra. For å halde eit slikt arbeid levande trengst det organisering og ressursar - ein kan ikkje satse på vedvarande dugnad.

Vi treng gode kommunikasjonsverktøy, først og fremst datasystem som fungerer i kvardagen slik at vi kan utveksle informasjon ved behov.

Vi treng styrking av primærhelsetenesta, fleire legar, men også andre faggrupper, og ressursar til å yte gode omsorgs- og rehabiliteringstenester.

\section{Kva får vi?}

Vi får kommunal medfinansiering. Fleire milliardar blir sende inn i ein runddans der dei blir tatt frå budsjetta til helseføretaka og sette inn i rammene til kommunane, så reknar staten ut kor mykje innbyggarane har brukt sjukehusa og så skal kommunane betale pengane tilbake til sjukehusa. Det er ikkje, og skal ikkje vere, kommunane som avgjer kven som skal leggjast inn og sendast til behandling. Kommunane har såleis berre marginal innverknad på denne pengestraumen. Dette er pengeflytting som aukar sysselsettinga blant pengeflyttarane og tappar ressursar frå helsetenesta.

\section{«Det er ein stor og reell} fare for at dette systemet vil svekke kommunane økonomisk og gjere det vanskelegare å styrke førebygging og eigne tenestetilbod»

Kommunane treng meir ressursar dersom dei skal yte betre og meir omfattande tenester. Det er ein stor og reell fare for at dette systemet vil svekke kommunane økonomisk og gjere det vanskelegare å styrke førebygging og eigne tenestetilbod.

Vi får eit avtalesystem mellom kommunestyre og helseføretak. Avtalane omfattar sentrale områder som ansvarsfordeling, innlegging og utskriving av pasientar, beredskap, kommunal øyeblikkeleg hjelp i eigne institusjonar, kunnskapsoverføring, fors- king, faglege nettverk, IKT-løysingar med meir. Avtalane skal inngåast under tidspress utan at det er rom for refleksjon, utgreiing og forankring, noko som er nødvendig for å få til gode løysingar. Den mest sentrale samhandlingsaktøren i kommunane, fastlegane, har ingen plass i avtalesystemet. I skrivande stund, seks veker før reformen skal tre i kraft, er enno ikkje sentrale forskrifter som legg premiss for dette arbeidet på plass.

Vi får ei IT-satsing på papiret. I realiteten ikkje er ho ikkje god nok til å sikre oss dei arbeidsverktøya vi treng og det som skal til for at dei skal snakke godt samen.

Vi får ikkje den satsinga vi treng på eit godt fagleg utviklingsarbeid mellom fastlegar og sjukehusspesialistar for verkeleg å utvikle samhandling.

Vi treng ein samhandlingsreform, men denne reformen er på feil spor.

\section{Ottar Grimstad}

ottar@grimstad.me

Hareid legesenter

Hareid

Ottar Grimstad (f. 1950) er spesialist i allmennmedisin og samfunnsmedisin og kommuneoverlege og fastlege i Hareid kommune. Ingen oppgitte interessekonflikter. 